\title{
Effects of climate change on bioclimatic indices in vineyards along Lake Neuchatel, Switzerland
}

\author{
Valentin Comte $^{1,2} \cdot$ Léonard Schneider $^{1,2} \cdot$ Pierluigi Calanca $^{3} \cdot$ Martine Rebetez $^{1,2}$
}

Received: 3 March 2021 / Accepted: 20 October 2021 / Published online: 30 October 2021

(c) The Author(s) 2021, corrected publication 2022

\begin{abstract}
In this study, we investigated the consequences of climate change on bioclimatic indices in vineyards along the edge of Lake Neuchatel in Switzerland. Like in other vineyards all around the world, the typicity of wines and the phenology of vines have changed, particularly since the 1970s. Trends in the growing season average temperature and in Huglin's heliothermal index show that the climate in the Neuchatel vineyards changed from very cool or cool to temperate during the last decades. Trends in the cool night index and in the prior to harvest cool night index both indicate that in the near future this wine region will frequently experience temperate instead of cool nights during the weeks leading up to harvest. Our results highlight the need for adaptation strategies, such as an upward elevational shift for Pinot Noir, as climatic conditions will become too warm at its current location in the next decades. They also show that conditions in this region are already favorable for more thermophilic varieties such as Merlot. In the context of global warming, this kind of analysis should be conducted throughout winegrowing regions in order to develop efficient adaptation strategies at the microclimatic scale.
\end{abstract}

\section{Introduction}

Grapevines are cultivated in specific regions according to the particular temperature needs of each variety and to a process of selection and experimentation conducted by winegrowers (Huglin and Schneider 1998; Jones 2007; Moriondo et al. 2013; Unwin 2005). This process explains the existence of wine regions, which are characterized by specific wine typicities (Jones 2007). It has been shown that, in addition to climate, other elements play an important role in the production of quality wines, such as soil type and depth, cultural and oenological practices, evapotranspiration, rooting depth, leaf area, and the interactions between all these factors (Huglin and Schneider 1998). As an example, slight water stress, which depends on rainfall, temperature, and leaf area, improves wine quality (Spring and Zufferey 2009; van Leeuwen et al. 2009), but excessive water stress has negative

Valentin Comte

valentin.comte@unine.ch

1 Institute of Geography, University of Neuchatel, Espace Tilo-Frey 1, 2000 Neuchatel, Switzerland

2 Swiss Federal Institute for Forest, Snow and Landscape Research (WSL), Neuchatel, Switzerland

3 Agroscope Reckenholz, Zurich, Switzerland impacts. Winegrowers have the possibility to reduce these impacts by using an irrigation system (Santillán et al. 2019; van Leeuwen et al. 2009).

Weather conditions are still considered the most important factor for viticulture (Jones and Davis 2000; van Leeuwen et al. 2004). Numerous studies have shown that rising air temperatures undoubtedly have an impact on the phenological development stages of grapes (e.g., Cook and Wolkovich 2016; Cuccia et al. 2010; Duchêne and Schneider 2005; Fraga et al. 2016; Jones and Webb 2010; Lebon 2002; Seguin and Garcia de Cortazar 2005; Tomasi et al. 2011; Urhausen et al. 2011). Air temperature rise, combined with ever-earlier grape harvests, changes the typicity and character of the wines produced (Jones and Webb 2010; Spayd et al. 2002; van Leeuwen and Darriet 2016). Thus, the final sugar concentration and potential alcohol content of wines both tend to increase, while total acidity decreases (Battaglini et al. 2009; De Orduna 2010). Other aromatic and phenolic elements are also altered (De Orduna 2010; Dequin et al. 2017). Cool conditions prior to harvest are known to positively influence total phenolics, and to give wine a specific color (Kliewer 1973; Kliewer and Torres 1972; Moriondo et al. 2013), particularly for Pinot Noir (Nicholas et al. 2011; Shaw 2012). Thus, the composition of grapes changes considerably with an overall rise in air temperature, modifying the typicity of the wines. 
Beyond rising temperatures, it has been shown that climate change could lead to an increase in spring frost risk, in heat wave duration and occurrence, and in solar radiation, all of which increase the risk of sunburn to grapevines (Sgubin et al. 2018; Stock et al. 2005). Furthermore, climate change is expected to result in a shift in the geographic distribution of different pathogens and insect pests, which is likely to increase the risk of disease and infestation in winemaking regions with historically cold climates, i.e., $13-15^{\circ} \mathrm{C}$ on average for the grapes' growing period (Boudon-Padieu and Maixner 2007; Tate 2001).

As regional implications of climate change and adaptation possibilities differ for each vineyard, it is necessary to focus on studies at the local scale (Pons et al. 2017; Ramos Martín et al. 2018), taking winegrowers into account in order to suggest manageable adaptation solutions (Boyer 2016).

Changing climatic conditions will progressively result in a latitudinal shift of the vine suitability zone (Jones and Alves 2012; Jones et al. 2005). In particular, southern vineyards in the Northern Hemisphere will probably become too hot for producing high-quality wines (Stock et al. 2005). It is expected that long-term adaptation solutions for vineyards in other regions will involve the introduction of new varieties (more thermophilic and/or resistant to pests and pathogens) and/or an elevational shift (Jones et al. 2005; Schultz 2000).

In Switzerland, the mean annual temperature increased by $1.8^{\circ} \mathrm{C}$ between the beginning of temperature measurements in 1864 and 2016 (MeteoSwiss 2016). Rebetez and Reinhard (2008) observed that the trend reached $+0.57^{\circ} \mathrm{C}$ per decade from 1975 to 2004. Thus, climate warming in Switzerland is currently more than twice the average over the Northern Hemisphere. The temperature rise is not uniform through the year: spring and summer are warming more than winter and autumn. This point is crucial for viticulture, as the vine growing season extends from 1 April to 31 October. The beginning and middle of the growing season are therefore warming more than the end, with September having the smallest temperature increase.

Air temperature impacts on grapevines are well known and considered the main determining factor for the development of this cultivated plant, particularly for bringing it to maturity (Huglin and Schneider 1998). Using air temperature data, a large number of bioclimatic indices have been developed (Table 1). They indicate the suitability of each region for producing specific vine varieties (Briche et al. 2014; Huglin and Schneider 1998). Most consist of a heat accumulation of degree days with a $10^{\circ} \mathrm{C}$ lower limit, such as the Winkler index (Amerine and Winkler 1944), Huglin's heliothermal index (Huglin 1978), Branas' heliothermal index (Branas 1974), biologically effective degree days (Gladstones 1992), and the sum of average temperature (Jones and Davis 2000). Huglin's heliothermal index (HI) has been used to define vine culture availability for some varieties. It offers the highest correlation coefficient with sugar content, which represents grape maturity (Huglin and Schneider 1998). Sugar is the most important factor for producing highquality wine in cool climate regions, especially when the grape varieties are close to their low-temperature limits of possible cultivation (Huglin and Schneider 1998). By contrast, maintaining acidity is the most important challenge in warm climate regions (Huglin and Schneider 1998). The growing season average temperature, used by Jones et al. (2005), defines the suitability for growing specific grape varieties by considering the average temperature of the growing season (1 April to 31 October; GST). The cool night index (CI) (Tonietto and Carbonneau 2004) and the Fregoni index (FI) (Fregoni 2003) count the occurrences of low-temperature periods before harvest, which are important for wine composition
Table 1 Bioclimatic indices, the corresponding equations for the Northern Hemisphere, and literature sources, adapted from Jones et al. (2005), Blanco-Ward, Queijeiro, and Jones (2007), and Resolution OIV VITI 423-2012 (2012). Tmax is daily maximum temperature, $T$ min is daily minimum temperature, and Tmean is daily mean temperature $((T \max +T \min ) / 2) . k$ is a constant depending on latitude (40 to $50^{\circ}$ ) spanning from 1.02 to 1.06 ; Ie is effective insolation; $d$ is the number of hours per day where $T<10^{\circ} \mathrm{C} ; W_{0}$ is the water reserve at the beginning of the period; $P$ is monthly precipitation; $T \mathrm{~V}$ is monthly vine transpiration; $E$ s is monthly soil evaporation.

\begin{tabular}{llll}
\hline Index name and abbreviation & Equation & Period & Source \\
\hline Winkler index (WI) & $\sum(T$ mean -10$)$ & 1 Apr. to 31 Oct. & Amerine and Winkler (1944) \\
Huglin's heliothermal index (HI) & $k * \sum\left(\frac{T \text { mean }+T \text { max }}{2}-10\right)$ & 1 Apr. to 30 Sep. & Huglin (1978) \\
Branas index (BHI) & $\sum(T \operatorname{mean}-10) * \sum\left(I \mathrm{e} * 10^{-6}\right)$ & 1 Apr. to 31 Oct. & Branas (1974) \\
Biologically effective degree days (BEDD) & $\sum \min \{\max [T$ mean $-10 ; 0] ; 9\}$ & 1 Apr. to 31 Oct. & Gladstones (1992) \\
Sum of average temperature (SAT) & $\sum(T \operatorname{mean}>10)$ & 1 Apr. to 31 Oct. & Jones and Davis (2000) \\
Growing season temperature average (GST) & $\operatorname{Avg}(T \operatorname{mean})$ & 1 Apr. to 31 Oct. & Jones et al. (2005) \\
Cool night index (CI) & $\operatorname{Avg}(T \min )$ & September & Tonietto and Carbonneau (2004) \\
Fregoni index (FI) & $\sum(T \max -T \min ) * \sum N_{d} T<10$ & September & Resolution OIV VITI 423-2012 \\
& $\sum W \mathrm{O}+P-T \mathrm{v}-E \mathrm{~s}$ & (2012) & Riou et al. (1994) \\
Dryness index (DI) & & &
\end{tabular}


(Moriondo et al. 2013). CI corresponds to mean September daily minimum temperature (Tmin). FI is defined as daily $T$ max minus daily $T$ min, summed over all days in September and then multiplied by the number of days in September with $T$ mean below $10^{\circ} \mathrm{C}$. The dryness index (DI) calculates a water balance, considering the water reserve at the beginning of the ripening period, incoming water and outgoing water.

In this study, we assessed trends in relevant bioclimatic indices for Neuchatel (Switzerland) vineyards, considering two grape varieties and trends in climate parameters since 1900. We focused on the trends in GST, HI, and CI, taking the period prior to harvest into account, and investigated their consequences for two grape varieties (Pinot Noir and Merlot). Understanding these trends will help to predict future short-term prospects for the vineyards.

\section{Materials and methods}

\subsection{Study area}

The vineyards of Neuchatel, Switzerland, are located to the south-south-east of the Jura foothills (Fig. 1). The vineyards are located on the shores of Lake Neuchatel and Lake Biel, between 430 and $550 \mathrm{~m}$ a.s.l. Although Chasselas was historically the main grape variety cultivated in this region, it was gradually replaced by other varieties, mainly Pinot Noir. Vineyards currently cover approximatively 600 ha and produce mostly Pinot Noir (55\%) and Chasselas (27\%), but also other varieties such as Pinot Gris $(<4 \%)$, Chardonnay $(<4 \%)$, Merlot $(<1 \%)$, Cabernet Franc $(<0.5 \%)$, Divico $(<0.5 \%)$, Galotta $(<0.5 \%)$, and Malbec $(<0.5 \%)$ (Cartillier 2018). The grapevines are mainly planted on a south-southeast-facing slope, although some vineyards exist on flat land

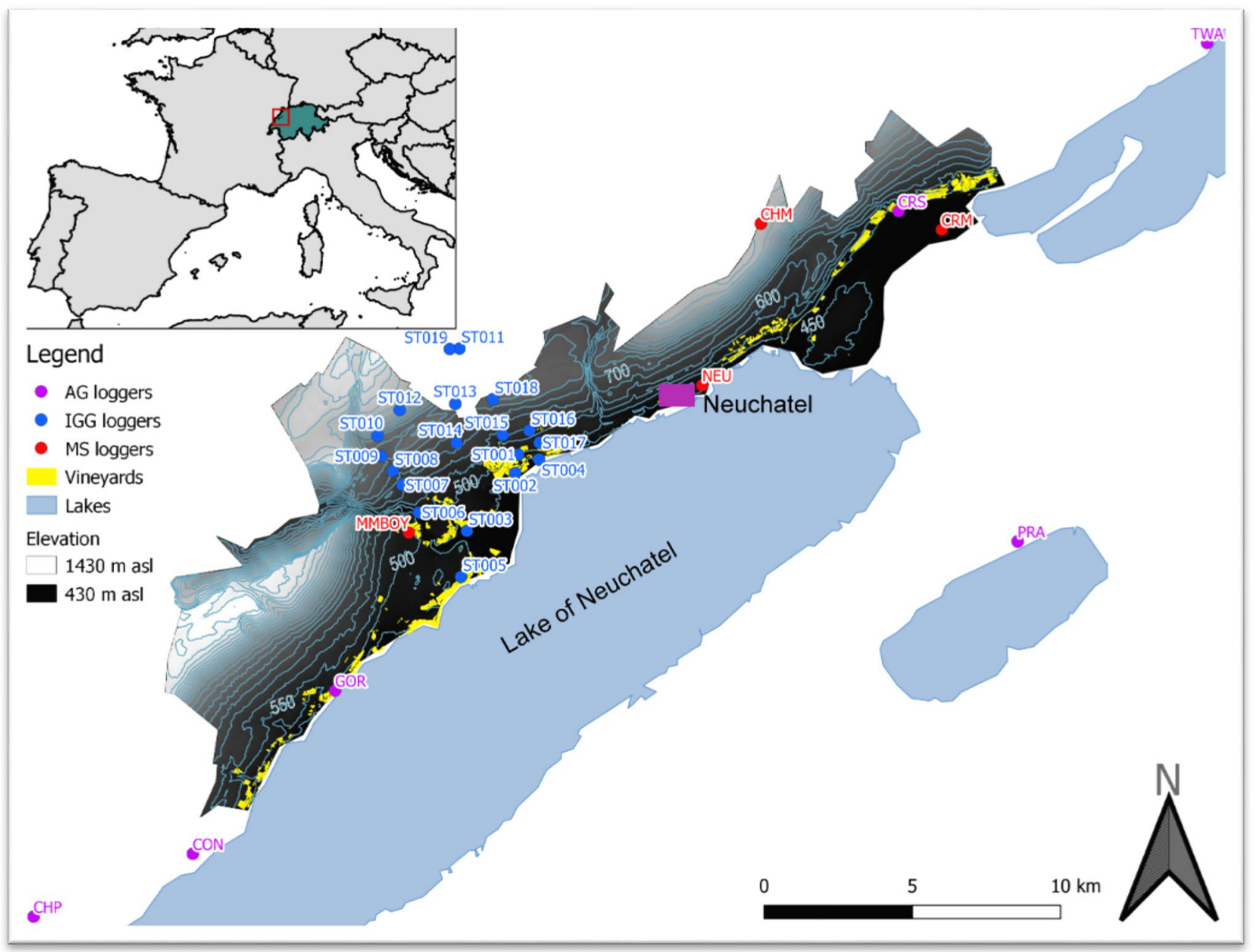

Fig. 1 Location of the study area, vineyards, and temperature loggers. AG loggers are temperature loggers from Agrometeo, IGG loggers are loggers from the Geography department of the University of Neuchatel, and MS loggers are loggers from MeteoSwiss 
by the lakes. According to Köppen's climate classification adapted by Peel et al. (2007), the region is characterized by a temperate and humid continental climate. Its grapevine climate is considered cool according to Jones' classification (Jones 2006).

\subsection{Data}

We used daily air temperature minima (Tmin) and maxima (Tmax) data to compute and analyze various bioclimatic indices. These data originated from 29 temperature loggers, provided by three sources: our own loggers (19), Agrometeo (6) (http://www.agrometeo.ch/fr/meteorology/datas), and MeteoSwiss (4) (https://gate.meteoswiss.ch/idaweb/). All loggers record air temperature at $2 \mathrm{~m}$ above ground. Our own loggers (Fig. 1: IGG loggers) were installed in 2017. They are located in and above the vineyards in order to collect precise, local data (Fig. 1 and Table 3). The other stations are representative of the topographic and elevational situation of Neuchatel's vineyards. All of them are located in the vineyards or slightly higher in similar geographical conditions. MeteoSwiss Neuchatel (NEU) is our main meteorological long-term reference station, with temperature data available since 1864. Four Agrometeo stations (AG loggers) are located outside the study area, in nearby south-southeast-facing slopes and lakeshores in winegrowing areas with similar topographic and climatic conditions. The CRM and CHM MeteoSwiss stations (Fig. 1) are not representative of the geographical situation of the vineyards. The CRM station is located on a valley floor near a small river. It is therefore exposed to cold air pools and a high spring frost risk. Consequently, vines are not cultivated in this area (Fig. 1). The CHM station is on a mountain peak at $1136 \mathrm{~m}$ a.s.l. These two stations provide a comparison between the vineyard climate and microclimates that are colder because of elevation or topography. We used homogeneous data series starting in 1900 to compute the average trend in Switzerland mean growing season temperature (GST) in order to make comparisons between the study region and the average of 14 MeteoSwiss representative stations in Switzerland. However, at two stations, data were only available starting in 1964 (PAY) or 1879 (CHD) rather than 1864.

We used the standard WMO (World Meteorological Organization) method to compute daily mean temperature at each station:

$T$ mean $=\frac{T \max +T \min }{2}$

Harvest dates were recorded from 1970 to 2017 by the Station viticole cantonale of Neuchatel, which did not record dates in 2018 and 2019. For these two years, harvest dates were estimated using our own phenological observations. Harvest dates correspond to the average date of the beginning of the harvest period in Neuchatel's vineyards each year, based on Chasselas and Pinot Noir. Chasselas is normally harvested a few days later than Pinot Noir.

\subsection{Methods}

We chose Huglin's heliothermal index (HI) as the reference bioclimatic index rather than other indices based on the accumulation of growing degree days (GDD), as it appeared to show the highest correlation with sugar content at harvest (Huglin 1978). There were many missing values (NA) at some Agrometeo stations, which made it difficult to compute HI. Therefore, we replaced all NA values with predicted values using a lapse rate model. Elevation is known to be the main factor explaining air temperature differences at the regional scale (Joly et al. 2012). We used all stations for which we had data from 2007 or earlier to determine a mean lapse rate per month based on 13 years of daily mean and maximum temperatures. We crossed all measured daily temperature data with predicted data for all stations to check the quality of the model. It gave good results for both Tmean $\left(R^{2}=0.98\right.$ and $\left.p<0.001\right)$ and $T \max \left(R^{2}=0.97\right.$ and $\left.p<0.001\right)$ [Fig. 7]. The model made it possible to replace 1385 (out of $74,900)$ missing values with predicted values. This model was also applied to estimate past climatic conditions and produce a map indicating past HI values in the study area.

We used homogenized temperature data from the MeteoSwiss NEU station to compute trends in all bioclimatic indices (GST, HI, CI, and "prior to harvest cool night index" [PHCI; described below]), as these data had already been homogenized for our study period. This station is located at $485 \mathrm{~m}$ a.s.l., which is approximatively the average of the vineyards' elevation range (430 to $550 \mathrm{~m}$ a.s.1.). This station thus offers a representation of the mean climate in our vineyard study area. The other stations were used to produce high-precision climatic maps by considering their lapse rate.

We first focused on the trends in GST. This bioclimatic index is currently used to define the suitability of climatic conditions for the growth of specific grape varieties (Jones et al. 2005). Second, we analyzed the trends in HI. We produced high-resolution maps illustrating the elevational variability of this index and the interannual variability characterizing these vineyards. We used Pinot Noir and Merlot optimum estimations based on Huglin and Schneider (1998) to illustrate vine culture optimal conditions based on climatic parameters. These optima represent climate conditions under which grapes contain 180-200g/l of sugar (Huglin and Schneider 1998). These optima are not applied strictly because sugar content depends on other factors as well, such as yield and irrigation system (Huglin and Schneider 1998). We analyzed trends in CI as the third bioclimatic index. Finally, we computed a new index based on the dates of the harvest period (prior to harvest cool night index; PHCI). 
Indeed, as the cool night index is based on September temperatures, it does not always fit with the current harvest period. Our new index is computed using the mean daily Tmin during the 30 days prior to harvest. This index has the advantage of taking into consideration changes in harvest dates and actual $T \mathrm{~min}$ values that grapes experience prior to harvest. Both CI and PHCI were used to determine the occurrence of cool night periods, which are important for wine composition (Moriondo et al. 2013).

Prior to harvest cool night index (PHCI) $=$ $\frac{1}{30} \sum_{H \mathrm{~d}-30}^{H \mathrm{~d}} T \mathrm{~min}$, where $H \mathrm{~d}=$ annual average date of the harvest period.

We used the program $\mathrm{R}$ to compute all statistical tests (R Core Team 2013).

\section{Results}

\subsection{Trends in average growing season temperature since 1900}

The growing season temperature average according to Jones et al. (2005) refers to the average daily Tmean from 1 April to 31 October (Table 1). The trends since 1900 in GST on average across Switzerland (a) and for the station NEU (b) are shown in Fig. 2. We used the 14 MeteoSwiss reference stations to compute the Swiss average. Two segmented regressions produced two breaking points and three periods for both Switzerland and NEU. For Switzerland, the first period (1900 to 1947) was characterized by an increase of $0.23^{\circ} \mathrm{C}$ decade $^{-1}(p<0.001)$, the second period $(1947$ to 1974 ) by a decrease of $0.16^{\circ} \mathrm{C}$ decade $^{-1}(p<0.01)$, and the third period (1974 to 2019) by an increase of $0.57^{\circ} \mathrm{C}$ decade $^{-1}(p<0.001$; Fig. 2b). For NEU, the segmented regression indicated the same three periods, but only two of them showed a significant change in GST: the first one (1900 to 1947) with an increase of $0.25^{\circ} \mathrm{C}$ decade $^{-1}$ and the third one (1974 to 2019) with an increase of $0.55^{\circ} \mathrm{C}$ decade $^{-1}$, both highly significant $(p<0.001)$. The second interval (1941 to 1973) showed a slight decrease of $0.23^{\circ} \mathrm{C}$ decade $^{-1}$ (not significant; $p=0.063$ ).

The 11-year moving average (MovAve) confirmed this general trend in GST, with a clear increase only since the 1970s for both Switzerland and NEU (Fig. 2). A linear model was computed, showing a trend from 1974 to 2019. 1974 corresponded to the second breaking point produced by the segmented regression. The linear model showed trends similar to those in the third part of the segmented regression for both Switzerland, with an increase of $0.59 \pm 0.06^{\circ} \mathrm{C}$ per decade ( $p<0.001$ and $\left.R^{2}=0.72\right)$, and the NEU station, with an increase of $0.56 \pm 0.06^{\circ} \mathrm{C}$ per decade $(p<0.001$ and $R^{2}=0.65$ ). Predictive intervals at $90 \%$ and $95 \%$ (PI.90 and
PI.95) show the interannual variability of both Switzerland and NEU (Fig. 2).

According to Jones' classification (Jones 2006), the climate in the region of Neuchatel was cool during the 1970s. The average GST was $14.2^{\circ} \mathrm{C}$. The predictive interval (PI.90) during that decade ranged from 13.2 to $15.2^{\circ} \mathrm{C}$. Following the increase in GST over the period 1974 to 2019, the climate was labeled intermediate during the 2010s. The average GST was $16.3^{\circ} \mathrm{C}$ and the predictive interval (PI.90) was between 15.3 and $17.3^{\circ} \mathrm{C}$ during the period 2010-2019. Figure 2 shows that Neuchatel experienced trends in GST and in PI similar to those of the Swiss average.

\subsection{Huglin's heliothermal index: trends, maps, and variability}

The trend since 1900 in Huglin's heliothermal index (HI; Huglin and Schneider 1998) for the station NEU is shown in Fig. 3. The computed segmented regression indicated three periods, all of them showing significant changes in HI: the first one (1900 to 1949) was characterized by an increase of $39.4 \pm 14.7$ per decade $(p<0.001)$ and the third one $(1972$ to $2019)$ by an increase of $103.7 \pm 15.1$ per decade $(p<0.001)$. During the period from 1950 to 1971 , this index decreased slightly by $77 \pm 47.2(p<0.05)$.

The 11-year moving average (MovAve) showed a similar general behavior. A linear model was computed, producing a mean trend from 1972 to 2019. It differed least from the third part of the segmented regression, as it increased by $111 \pm 14.6$ per decade $\left(p<0.001\right.$ and $\left.R^{2}=0.55\right)$. Figure 3 shows that the mean $\mathrm{HI}$ in Neuchatel vineyards presently lies between the theoretical optimum for Pinot Noir and for Merlot.

The maps in Fig. 4 make it possible to compare $\mathrm{HI}$ in our study region between two periods, the 1970s (Fig. 4a) and the 2010s (Fig. 4b).

Figure 4 shows that the grapevine climate based on the HI classification has changed during the study period. In the 1970s, mean HI values reached between 1300 and 1500 in our study region. These values correspond to the minimum theoretical limit for vine growth (Huglin and Schneider 1998). The vineyards' climate during that period could be considered very cool. In 40 years, the HI values have increased by approximatively 400 (Figs. 3 and 4). On average, the vineyards now belong to the temperate climate classification. According to this bioclimatic index, the Neuchatel vineyards should therefore be gradually adapted, with more thermophilic varieties such as Merlot or Malbec planted at lower elevations. The HI values observed at lower elevations during the 1970s were measured approximately $300 \mathrm{~m}$ higher in the 2010s, between 700 and $800 \mathrm{~m}$ a.s.l.

Interannual temperature variability has always been high in our study region. For the growing season, this variability 

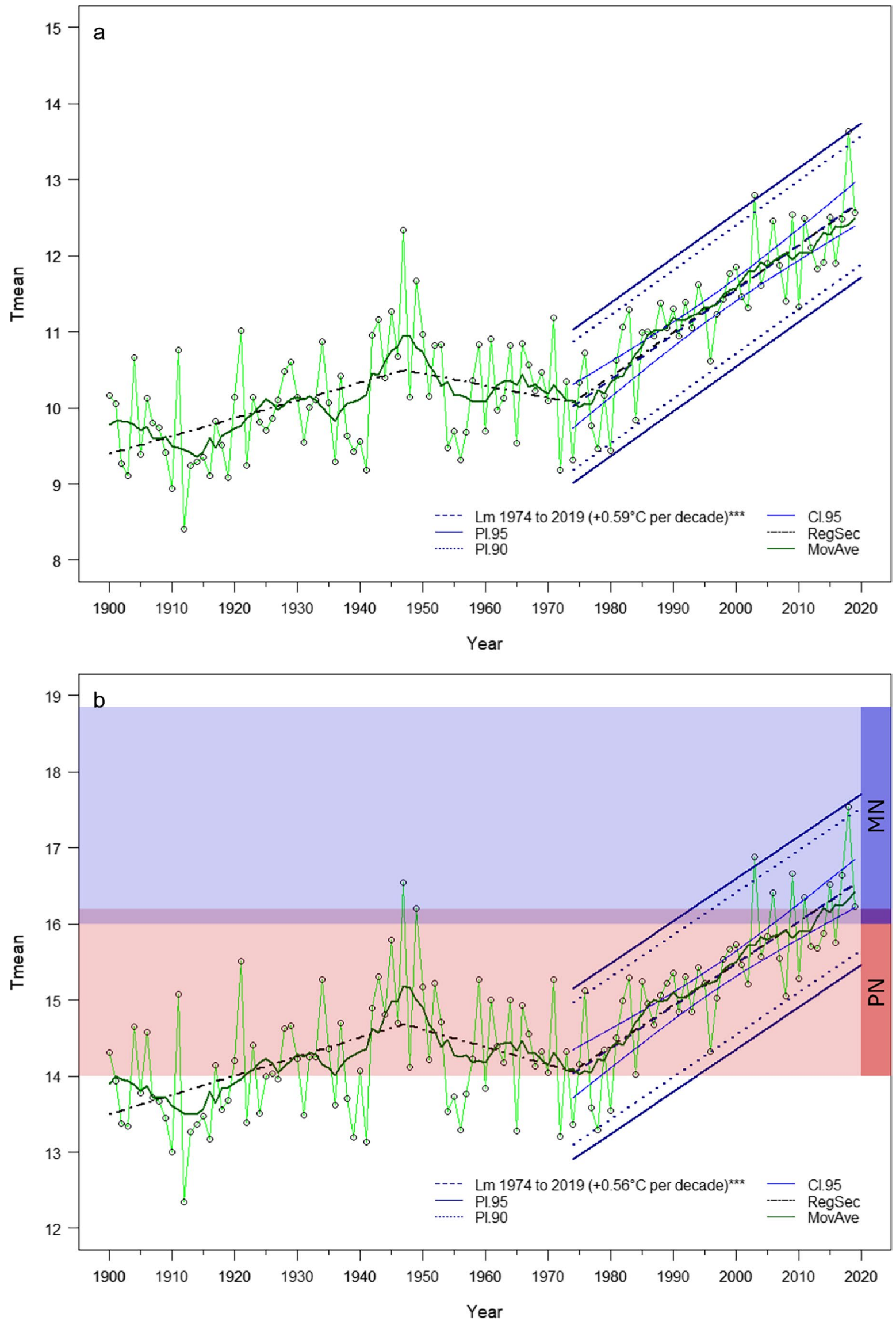
4Fig. 2 Trends in the growing season temperature (GST) averages in Switzerland (a) and at the NEU station (b) from 1900 to 2019. The $\mathrm{PN}$ red band and MN blue band in (b) indicate the GST suitability for Pinot Noir and Merlot, respectively, with a $\pm 0.2-0.5^{\circ} \mathrm{C}$ error margin, based on GST according to Jones (2006). Lm 1974 to 2019 is the linear model, “***" indicates that $p<0.001$. The two curved blue lines around the linear model indicate the confidence interval. They show the mean standard error of this model, which corresponds to the year-over-year variability of the index in the region. This interannual variability is represented in the graph by two predictive intervals, with $90 \%$ of the points inside for the first one (PI.90; dotted dark blue lines) and 95\% inside for the second one (PI.95; solid dark blue lines). They indicate that $\mathrm{HI}$ was located between these lines 9 years out of 10 for PI.90 and 19 years out of 20 for PI.95. The black dotted lines show the sequential regression. The dark green line shows the 11-year moving average (MovAve)

did not change significantly with increasing temperatures during the twentieth century (Luterbacher et al. 2004; Rebetez 2001). Our results indicate that the interannual variability in HI has not changed significantly either, in spite of increasing temperatures (Table 2). These values are highly determined by temperatures during the growing season. The variances of the periods 1970-1979 (27059.72) and 2010-2019 (25841.55) are quite similar. Note that the variance was very low during the decade 1990-1999. The interquartile ranges are also quite similar except for 1990-1999 and 2010-2019 (Table 2). Our results for PI.95 (Fig. 3), which are based on 50 years, show that HI varied by approximatively \pm 250 compared with the average for an especially cold or warm year.

As an illustration of the geographical consequences of this interannual variability during the last decade, the maps in Fig. 5 represent the conditions in two contrasting years. The year 2014 (Fig. 5a) was characterized by a colder and wetter growing season than on average during the last decade, and HI ranged from just below 1700 (lakeside) to 1500 (580 $\mathrm{m}$ a.s.1.). This year was clearly below the optimum HI for Merlot and also for Pinot Noir in a few vineyards. Although 2013 was even colder, we decided to analyze 2014 because a hail event destroyed most of the harvest in 2013. In contrast, 2018 (Fig. 5b) was characterized by a warm and

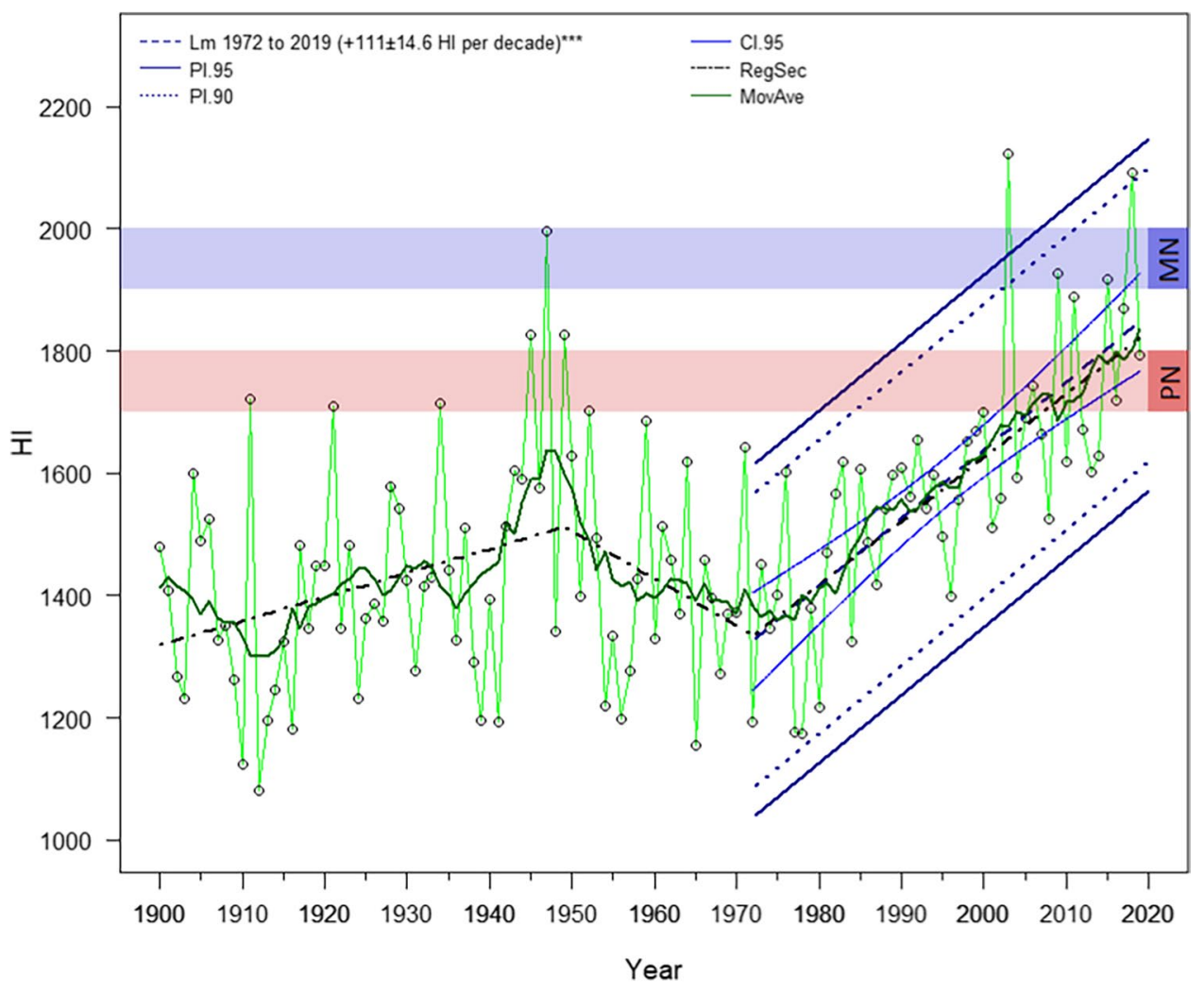

Fig. 3 Trends in Huglin's heliothermal index (HI) for the NEU station (485 m a.s.l.) from 1900 to 2019 (Jones 2006). Lm 1972 to 2019 is the linear model, "***" indicates that $p<0.001$. The two curved blue lines around the linear model indicate the confidence interval. They show the mean standard error of this model, which corresponds to the year-over-year variability of the index in the region. This interannual variability is represented in the graph by two predictive intervals, with $90 \%$ of the points inside for the first one (PI.90; dotted dark blue lines) and 95\% inside for the second one (PI.95; solid dark blue lines). They indicate that HI was located between these lines 9 years out of 10 for PI.90 and 19 years out of 20 for PI.95. They differ from the average by approximatively \pm 200 (PI.90) and \pm 250 (PI.95) in extreme years. The PN red band and MN blue band indicate the optimum HI for Pinot Noir and Merlot, respectively. The black dotted lines show the sequential regression. The dark green line shows the 11-year moving average (MovAve) 
Fig. 4 Mean Huglin's heliothermal index (HI) in the study region during the periods 1970 1979 (a) and 2010-2019 (b).

The four temperature loggers (4b) are represented by circles (only NEU station was available for $4 \mathrm{a}$ ). The represented values correspond to the mean HI values over each period. The isolines represent $50 \mathrm{~m}$ elevation classes, ranging from $430 \mathrm{~m}$ to more than $1000 \mathrm{~m}$ a.s.l. The color gradients indicate changes in $\mathrm{HI}$ in increments of 100.

Points show values measured by temperature loggers. PN (red) and MN (blue) bands indicate the optimum HI for Pinot Noir and Merlot, respectively
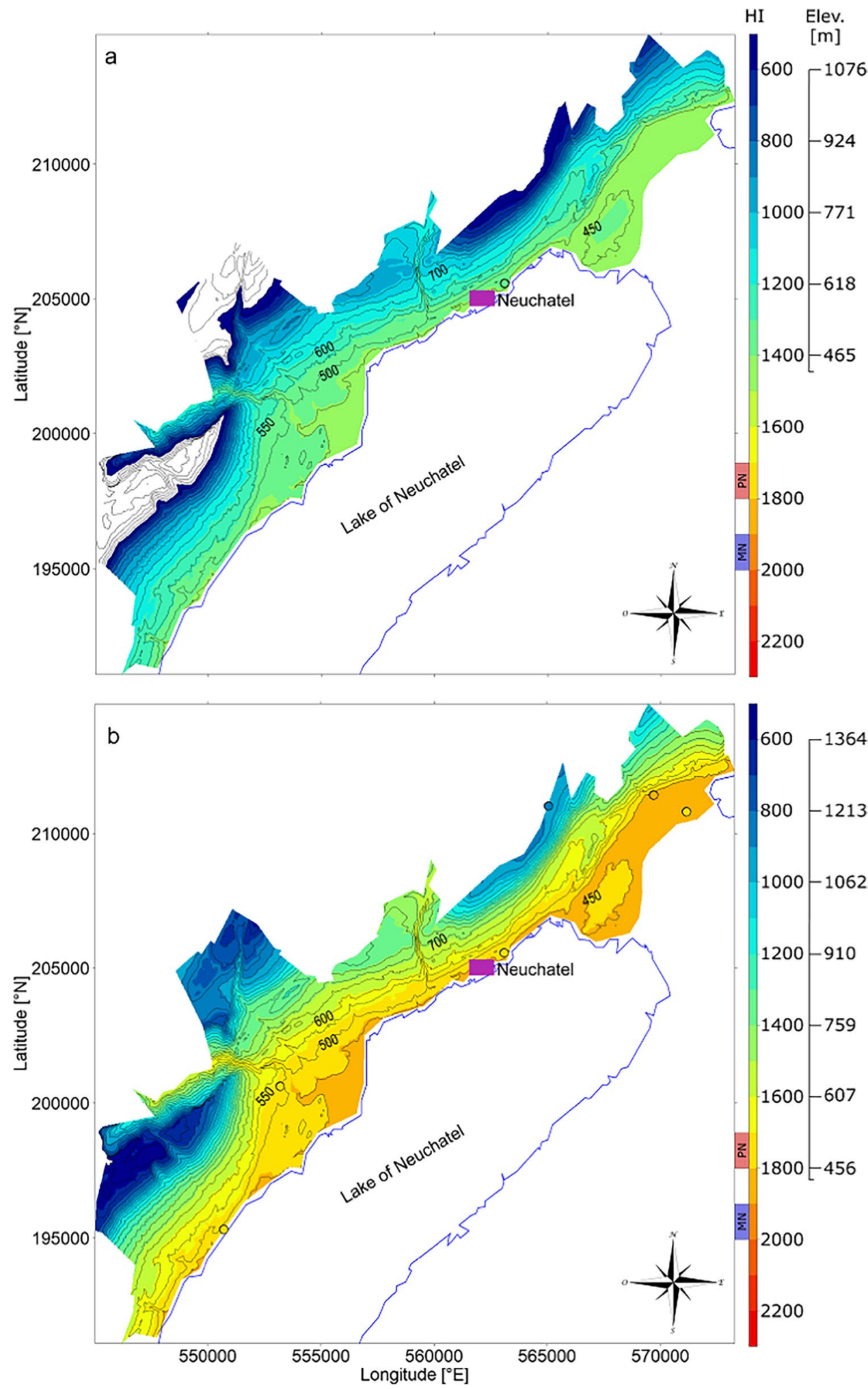

dry growing season, with the second highest (after 2003) HI since 1900 , with values ranging from 2200 by the lakeside (430 m a.s.1.) to 2000 at the highest vineyards' elevation (580 $\mathrm{m}$ a.s.l.). The year 2018 was outside of the predictive interval (PI.90) shown in Fig. 3. This year clearly had HI values above the optimum for Pinot Noir, and a few values even exceeded the optimum for Merlot. We asked the two producers of Merlot in 2014 to note the two vintages. They reported on average 11.5/20 for 2014 and 17/20 for 2018. 
Table 2 Average value of Huglin's heliothermal index (HI), variance (Var), standard deviation (Sd), and interquartile range (IQR) of each decade since 1970 for the NEU station

\begin{tabular}{llrrr}
\hline Decade & Average HI & \multicolumn{1}{l}{ Var } & \multicolumn{1}{c}{ Sd } & \multicolumn{1}{c}{ IQR } \\
\hline $1970-1979$ & 1374.1 & 27059.7 & 164.5 & 207.9 \\
$1980-1989$ & 1484.6 & 17457.9 & 132.1 & 159.2 \\
$1990-1999$ & 1573.8 & 6876.2 & 82.9 & 95.4 \\
$2000-2010$ & 1703.7 & 36922.3 & 192.2 & 165.9 \\
$2010-2019$ & 1779.8 & 25841.6 & 160.8 & 245.7 \\
\hline
\end{tabular}

The results show earlier harvest dates, with a trend of $-4.18 \pm 0.79$ days decade ${ }^{-1}$ (Fig. 6a). The cool night index (CI) was computed according to Tonietto and Carbonneau (2004). It has increased by $0.33 \pm 0.13^{\circ} \mathrm{C}$ per decade since the 1970 s, with $p<0.05$ and $R^{2}=0.1$ according to a linear model (Fig. 6b). The linear model for PHCI showed an increase of $0.95 \pm 0.16^{\circ} \mathrm{C}$ per decade, with $p<0.001$ and $R^{2}=0.39$. Note that PHCI was generally lower than CI until 1996 but has been increasing faster and has been mostly higher than CI since the beginning of the twenty-first century (Fig. 6b).

\section{Discussion}

The trends in bioclimatic indices for Neuchatel vineyards indicate a need for specific adaptation strategies in the future. Some studies, e.g., Santos et al. (2020) and Parker et al. (2020a, b), already highlighted that European vineyards will face an increase in air temperature associated with an advance in phenological stage of vine during the next decades, due to global warming. This could lead to a latitudinal shift in grape varieties. According to Morales-Castilla et al. (2020), southern Europe vineyards will decline while new vineyards could appear in northern Europe. In cool climate regions like Neuchatel, the vineyards will probably have to adapt by changing part of the cultivated varieties. This was also suggested by Molitor and Junk (2019) concerning Luxembourg vineyards. Wolkovich et al. (2018) highlighted that, due to the important increase in temperature expected for the next decades in Europe, adaptation strategies like the introduction of new varieties should already be considered in the vineyards of western Europe. Consequently, a change in cultivated varieties, for example, growing Merlot instead of Pinot noir along the lake, could now become an adaptation strategy for Neuchatel. Our results suggest that our study region now offers favorable temperature conditions for Merlot. They offer contrasting perspectives for viticulture suitability concerning the production of high-quality Pinot Noir and Merlot wines: trends in HI and GST suggest that the vineyards' climate will soon become too warm for Pinot Noir most of the time but suitable for Merlot more frequently. Concerning Pinot Noir in this region, our results show that it would make sense to investigate potential new areas for vineyards at higher elevations. If soils are properly adapted, Pinot Noir cultivation could be considered above $550 \mathrm{~m}$ a.s.1., which is the present regional official and legal upper limit for vineyards.

The present average $\mathrm{HI}$ in our study region lies between the theoretical optimum for Pinot Noir and for Merlot. As $\mathrm{HI}$ is based on daily mean and daily maximum air temperatures, it has been increasing in line with global warming and approximately twice faster warming observed in Switzerland (Pachauri et al. 2014; Rebetez and Reinhard 2008). Our analyses of HI, showing an increase of $111 \pm 14.6$ per decade, indicate a recent change in grapevine climate type category: the theoretical optimum was favorable for Pinot Noir until the first decade of the twenty-first century and was between the optimum for Pinot Noir and for Merlot during the second decade. The predictive interval in HI of approximatively \pm 250 between extreme years, such as 2018 (hot and dry) and 2014 (cold and rainy), shows important differences from year to year compared with the average decadal situation in terms of the conditions for vine cultivation. Descriptive statistics of each decade show quite similar variances and IQRs (interquartile ranges) for each decade except 1990-1999, which had less variability for these parameters (Table 2). The data distribution (Fig. 3) close to the average trend for all the years in this decade and the absence of an extreme year could explain this particularity. The presence in a decade of one or more extreme years that are much warmer (1971, 2003, and 2018) and/or much cooler (1977 and 1978) than the average should logically inflate the variance and IQR. Whatever the average values, winegrowers must adapt to high interannual variability.

The prior to harvest cool night index (PHCI) increased three times faster than the cool night index (CI) during the period 1970-2019. This is connected to the fact that the harvests usually took place in mid-October in the 1970s compared with mid- or end of September more recently (Fig. 6a). The upward trend in CI refers to the rather slow (compared with other months and with $T \max$ ) Tmin increase in September $\left(0.33 \pm 13^{\circ} \mathrm{C}\right.$ decade $\left.^{-1}\right)$. According to the classification for CI by Tonietto and Carbonneau (2004), the quality of Pinot Noir benefited from very cool night temperatures $\left(<12^{\circ} \mathrm{C}\right)$ in the past compared with recent cool temperature values $\left(12-14^{\circ} \mathrm{C}\right)$. PHCI analyses allowed us to consider the effective minimum temperature values before harvest, known to be determinant for wines' aromas and color (Kliewer 1973; Kliewer and Torres 1972; Moriondo et al. 2013). As harvests occur earlier, PHCI quantifies the occurrence of cool nights before the harvest, unlike CI. Our results for PHCI trend analyses indicate that, assuming a continuing similar temperature increase during the next 5-10 years, the average daily minimum temperature prior to the 
Fig. 5 Huglin's heliothermal index (HI) in the region of Neuchatel during a cold year (2014, a) and a warm year $(2018, b)$. The 6 and the 25 temperature loggers with data available in 2014 and 2018, respectively, are represented by circles
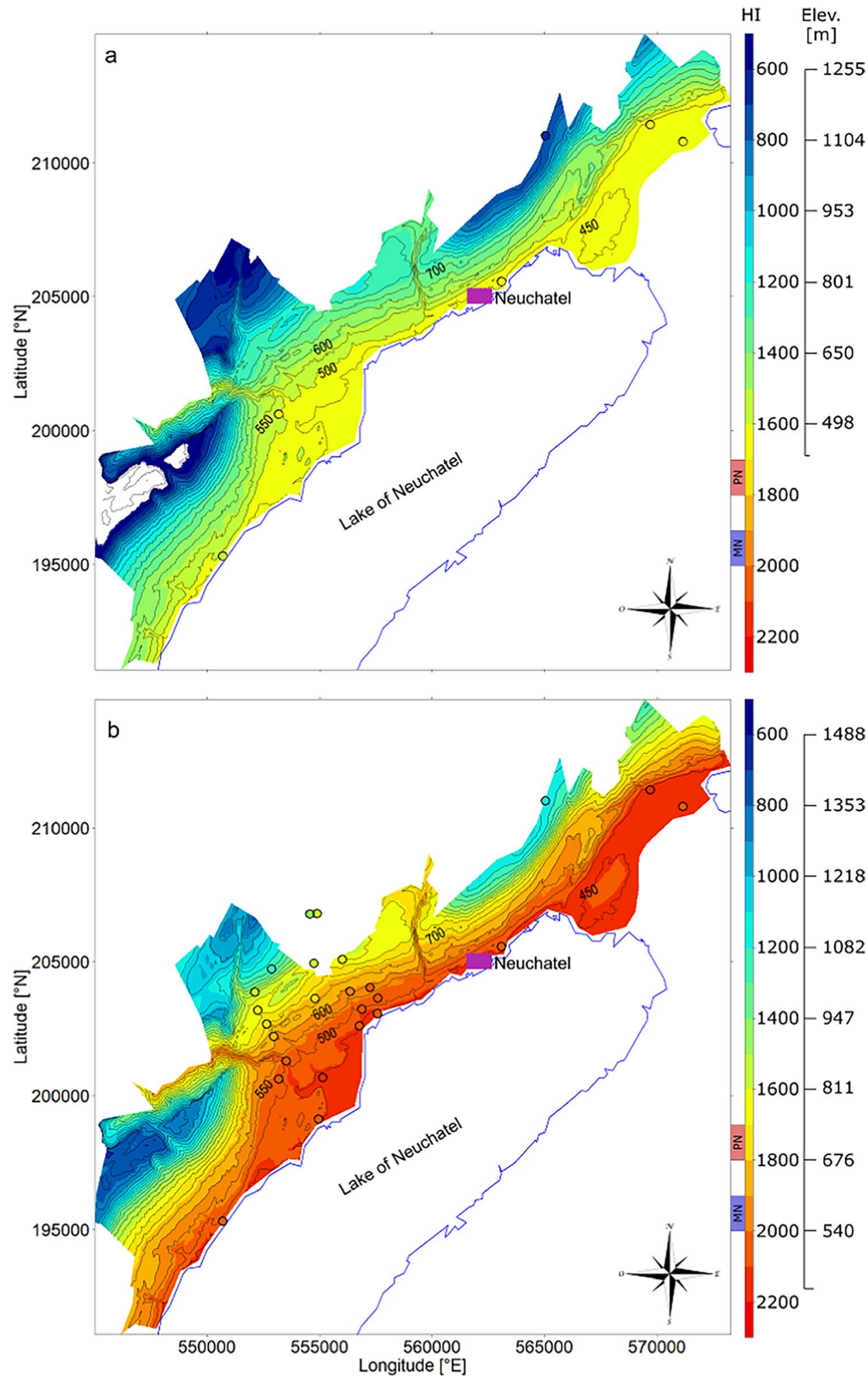

harvest period can be expected to exceed $14^{\circ} \mathrm{C}$. Such values are likely to impact the typicity and composition of Pinot Noir. Trends in GST are quite similar between Neuchatel and the Swiss average. Consequently, other Swiss wine regions can be expected to have similar adaptation needs.
All proposed climatic scenarios indicate that temperature will continue to increase in the Neuchatel region during the next decades (CH2018 2018). Our results show that producing meridional varieties, such as Merlot, could become an adaptation strategy in Neuchatel vineyards at 
Fig. 6 Average first day of harvest (a) and trends in cool night index (CI) and prior to harvest cool night index (PHCI; b) since 1970 at the NEU station
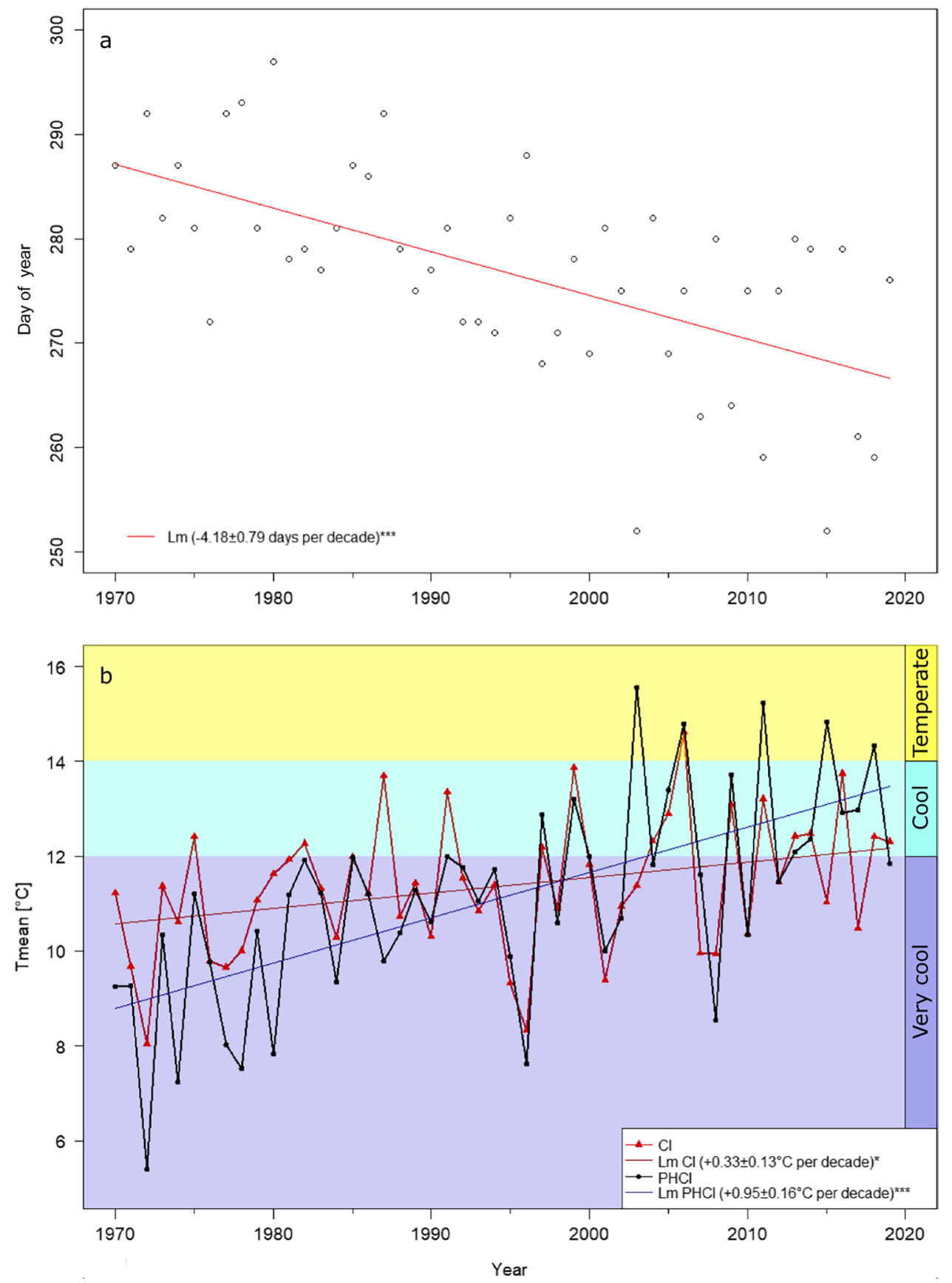

lower elevations. However, the success of such a strategy will depend on local and regional consumers' interest in these varieties, as the Neuchatel wine is sold almost exclusively in Switzerland (FOAG 2016).

Our study is based on temperature data only. Other climatic and non-climatic factors are also important for vine cultivation, although average temperature is clearly the main driver. Further studies should investigate other climatic factors, such as heat events and spring frost. Concerning the latter, the rather late budburst of Merlot compared with Pinot Noir corresponds to a lower spring frost risk. Climatic scenarios could give a better idea of the future conditions in Neuchatel vineyards. They could also provide indications of potential risks due to climate change.

Winegrowers have to deal with multiple parameters, and the choice of grape variety cannot be based on climatic considerations only. Our results do not take into account the specific adaptive capacities of the plant, changes in consumers' tastes, or the cultivation practices used by winegrowers (van Leeuwen et al. 2013). For example, some wine regions actually exceed the limits in terms of the mean temperature characteristics of the grape varieties they produce, without 
big impacts on the quality of their wines (van Leeuwen et al. 2013).

\section{Conclusions}

Our analysis of three bioclimatic indices shows important trends since the 1970s in the region of Neuchatel. We found an increase in GST by $0.56^{\circ} \mathrm{C}$ per decade since the $1970 \mathrm{~s}$. If the GST trend continues, the probability of having a year with a GST under $16^{\circ} \mathrm{C}$ will be lower than $10 \%$ within 10 years. Considering GST as an indicator for grape variety suitability, the climate of the Neuchatel region will become suitable for Merlot in the next decades. This trend also implies that adaptation strategies are needed for Pinot Noir. In 2018, GST was already too high for this variety, and it is likely that this situation will happen again during the next decades.

HI increased by more than 400 units during the study period. Consequently, according to this index, the Neuchatel vineyard climate passed from very cool to temperate during the last decades. Our results suggest potential future sugar content problems for Pinot Noir winemaking in this region.

Our results show that our new index, PHCI, is better suited than CI to characterize climate change impacts on vine growth and wine production in the context of climate change. Considering the low and non-significant increase in September temperatures, as well as the trend toward earlier harvests, CI no longer characterizes the real situation of cool nights during the period prior to harvest, even though it is a useful and easy tool for interannual and inter-regional comparisons. The increase in PHCI by $0.97^{\circ} \mathrm{C}$ per decade shows that the Neuchatel wine country will now mostly face temperate night conditions before harvest.

The four bioclimatic indices applied in the present study show that the considered region will soon face problems in the cultivation of Pinot Noir. A possible solution would be an upward elevational shift of vineyards. The climate of the region has changed rapidly in the last years and has become favorable for more thermophilic varieties at lower elevations. Our results highlight the urgent need for adaptation strategies for viticulture under global warming. In this context, it is crucial to conduct local climatic analyses in all winegrowing regions in order to develop adaptation strategies based on their results.

Supplementary Information The online version contains supplementary material available at https://doi.org/10.1007/s00704-021-03836-1.

Acknowledgements This research was funded by the Swiss Federal Office for the Environment (pilot program "Adaptation to climate change"), the canton of Neuchatel, winegrowing municipalities and wine producers' associations. Part of the temperature data was provided by MeteoSwiss (Swiss Federal Office of Meteorology and Climatology) and Agrometeo by Agroscope (Swiss centre of excellence for agricultural research). Harvest data were provided by Sebastien Cartillier, former director of the Station viticole cantonale of Neuchatel. The vineyard location shapefile was provided by the SITN (Système d'information du territoire neuchâtelois). The authors are grateful to Melissa Dawes for useful comments and suggestions for improving the manuscript and to Constant Signarbieux and Geoffrey Klein for their statistical advice.

Author contribution $\mathrm{VC}$ and $\mathrm{MR}$ designed the research and the paper. VC developed the R codes, carried out the statistical analyses, wrote the main part of the paper, and produced the map, tables, and figures. LS wrote part of the text and of the R codes. PC contributed to the analyses and wrote part of the text. MR wrote part of the text and guided the research and writing process.

Funding Open access funding provided by University of Neuchâtel. This research paper has been funded by the project D. 01 of the pilot program "adaptation to climate change" of the Federal Office for the Environment. It includes the financial participation of the Swiss Confederation, of the Canton of Neuchatel, of winegrowing localities and of winegrowing associations.

Availability of data and material The data availability from MeteoSwiss and Agrometeo is indicated in the data section of the paper. The data availability from our loggers can be asked to the corresponding author.

Code availability The R code used for the "Results" section can be asked to the corresponding author.

\section{Declarations}

Ethics approval No ethical issues are involved in this paper.

Consent to participate The authors gave their consent to participate.

Consent for publication The authors gave their consent for publication.

Conflict of interest The authors declare no competing interests.

Open Access This article is licensed under a Creative Commons Attribution 4.0 International License, which permits use, sharing, adaptation, distribution and reproduction in any medium or format, as long as you give appropriate credit to the original author(s) and the source, provide a link to the Creative Commons licence, and indicate if changes were made. The images or other third party material in this article are included in the article's Creative Commons licence, unless indicated otherwise in a credit line to the material. If material is not included in the article's Creative Commons licence and your intended use is not permitted by statutory regulation or exceeds the permitted use, you will need to obtain permission directly from the copyright holder. To view a copy of this licence, visit http://creativecommons.org/licenses/by/4.0/.

\section{References}

Amerine M, Winkler A (1944) Composition and quality of musts and wines of California grapes. Hilgardia 15:493-675

Battaglini A, Barbeau G, Bindi M, Badeck F-W (2009) European winegrowers' perceptions of climate change impact and options 
for adaptation. Reg Environ Change 9:61-73. https://doi.org/10. 1007/s10113-008-0053-9

Boudon-Padieu E, Maixner M (2007) Potential effects of climate change on distribution and activity of insect vectors of grapevine pathogens. Colloque international et pluridisciplinaire sous l'égide de la chaire UNESCO Vin et Culture, Dijon 2007:1-8

Boyer J (2016) L'implication des acteurs de la recherche dans les processus d'adaptation au changement climatique: l'exemple des régions viticoles françaises. Innovations 147-171 https:// doi.org/10.3917/inno.051.0147

Branas J (1974) Viticulture. Dehan, Montpellier, France, pp 1-346

Briche E, Beltrando G, Somot S, Quenol H (2014) Critical analysis of simulated daily temperature data from the ARPEGE-climate model: application to climate change in the Champagne wineproducing region. Clim Change 123:241-254. https://doi.org/ 10.1007/s10584-013-1044-5

Cartillier S (2018) Année viticole 2017. Station viticole cantonale de Neuchâtel, Neuchâtel

CH2018 (2018) Climate scenarios for Switzerland - technical report. National Centre for Climate Services, Zurich

Cook BI, Wolkovich EM (2016) Climate change decouples drought from early wine grape harvests in France. Nat Clim Change 6:715-721. https://doi.org/10.1038/nclimate2960

Cuccia C, Richard Y, Bois B, Castel T, Thevenin D (2010) Changement climatique : impacts sur la phénologie du Pinot Noir en Bourgogne. In: 23ème Colloque de l'Association Internationale de Climatologie, Rennes, France, 2010-09-01. Association Internationale de Climatologie, pp 143-148

De Orduna RM (2010) Climate change associated effects on grape and wine quality and production. Food Res Int 43:1844-1855. https://doi.org/10.1016/j.foodres.2010.05.001

Dequin S, Escudier J-L, Bely M, Noble J, Albertin W, MasneufPomarède I, Marullo P, Salmon J-M, Sablayrolles JM (2017) How to adapt winemaking practices to modified grape composition under climate change conditions. OENO One 51:205-214. https://doi.org/10.20870/oeno-one.2017.51.2.1584

Duchêne E, Schneider C (2005) Grapevine and climatic changes: a glance at the situation in Alsace. Agron Sustain Dev 25:93-99. https://doi.org/10.1051/agro:2004057

FOAG (2016) Rapport sur le système de contrôle des vins : Contrôles de la vendange et du commerce des vins. Confederation of Switzerland, Switzerland

Fraga H, Santos JA, Moutinho-Pereira J, Carlos C, Silvestre J, EirasDias J, Mota T, Malheiro AC (2016) Statistical modelling of grapevine phenology in Portuguese wine regions: observed trends and climate change projections. J Agric Sci 154:795-811. https://doi.org/10.1017/S0021859615000933

Fregoni M (2003) L'indice bioclimatico di qualità Fregoni. In: Fregoni M, Schuster D, Paoletti A (eds) Terroir, Zonazione, Viticoltura : Tratto internazionale. Phytoline, Rivoli, Italy, pp $115-127$

Gladstones J (1992) Viticulture and environment. Winetitles, Adelaide, Australia

Huglin P (1978) Nouveau mode d'évaluation des possibilités héliothermiques d'un milieu viticole. C R Acad Agric 1117-1126

Huglin P, Schneider C (1998) Biologie et écologie de la vigne. 2nd edition edn. TecDoc, Paris

Joly D, Bois B, Zaksek K (2012) Rank-ordering of popographic variables correlated with temperature. Atmos Clim Sci 02:139-147. https://doi.org/10.4236/acs.2012.22015

Jones G (2007) Climate change: observations, projections, and general implications for viticulture and wine production. Whitman College Economics Department working paper 7:1-14

Jones GV (2006) Climate and terroir: impacts of climate variability and change on wine:1-14. In: Macqueen RW, Meinert LD (eds) Fine wine and terroir - the geoscience perspective. Geoscience
Canada, Geological Association of Canada, St. John's, Newfoundland, Canada

Jones GV, Alves F (2012) Impact of climate change on wine production: a global overview and regional assessment in the Douro Valley of Portugal. Int J Glob Warming 4:383-406. https://doi. org/10.1504/IJGW.2012.049448

Jones GV, Davis RE (2000) Climate influences on grapevine phenology, grape composition, and wine production and quality for Bordeaux, France. Am J Enol Vitic 51:249-261

Jones GV, Webb LB (2010) Climate change, viticulture, and wine: challenges and opportunities. J Wine Res 21:103-106. https://doi. org/10.1080/09571264.2010.530091

Jones GV, White MA, Cooper OR, Storchmann K (2005) Climate change and global wine quality. Clim Change 73:319-343. https:// doi.org/10.1007/s10584-005-4704-2

Kliewer W (1973) Berry composition of Vitis vinifera cultivars as influenced by photo-and nycto-temperatures during maturation. J Am Soc Hortic Sci 98:153-159

Kliewer WM, Torres RE (1972) Effect of controlled day and night temperatures on grape coloration. Am J Enol Vitic 23:71-77

Lebon E (2002) Changements climatiques: Quelles conséquences pour la viticulture. In 6emes Recontres Rhodaniennes. Orange, France: Institut Rhodanien, pp 31-36

Luterbacher J, Dietrich D, Xoplaki E, Grosjean M, Wanner H (2004) European seasonal and annual temperature variability, trends, and extremes since 1500. Science 303:1499-1503. https://doi.org/10. 1126/science. 1093877

MeteoSwiss (2016) Rapport climatologique 2015. MeteoSwiss, Zurich

Molitor D, Junk J (2019) Climate change is implicating a two-fold impact on air temperature increase in the ripening period under the conditions of the Luxembourgish grapegrowing region. OENO One 53:409-422. https://doi.org/10.20870/oeno-one.2019.53.3. 2329

Morales-Castilla I, García de Cortázar-Atauri I, Cook BI, Lacombe T, Parker A, van Leeuwen C, Nicholas KA, Wolkovich EM (2020) Diversity buffers winegrowing regions from climate change losses. Proc Natl Acad Sci 117:2864-2869. https://doi.org/10. 1073/pnas. 1906731117

Moriondo M, Jones GV, Bois B, Dibari C, Ferrise R, Trombi G, Bindi M (2013) Projected shifts of wine regions in response to climate change. Clim Change 119:825-839. https://doi.org/10.1007/ s10584-013-0739-y

Nicholas KA, Matthews MA, Lobell DB, Willits NH, Field CB (2011) Effect of vineyard-scale climate variability on Pinot noir phenolic composition. Agric For Meteorol 151:1556-1567. https://doi.org/ 10.1016/j.agrformet.2011.06.010

Pachauri RK et al. (2014) Climate change 2014: synthesis report. Contribution of Working Groups I, II and III to the fifth assessment report of the Intergovernmental Panel on Climate Change. IPCC, Geneva

Parker AK, García de Cortázar-Atauri I, Gény L, Spring J-L, Destrac A, Schultz H, Molitor D, Lacombe T, Graça A, Monamy C, Stoll M, Storchi P, Trought MCT, Hofmann RW, van Leeuwen C (2020a) Temperature-based grapevine sugar ripeness modelling for a wide range of Vitis vinifera L. cultivars. Agric For Meteorol 285-286, 107902 https://doi.org/10.1016/j.agrformet.2020.107902

Parker AK, García de Cortázar-Atauri I, Trought MCT, Destrac A, Agnew R, Sturman A, van Leeuwen C (2020b) Adaptation to climate change by determining grapevine cultivar differences using temperature-based phenology models: This article is published in cooperation with the XIIIth International Terroir Congress November 17-18 2020, Adelaide, Australia. Guest editors: Cassandra Collins and Roberta De Bei. OENO One 54:955-974. https://doi.org/10.20870/oeno-one.2020.54.4.3861 
Peel MC, Finlayson BL, McMahon TA (2007) Updated world map of the Köppen-Geiger climate classification. Hydrol Earth Syst Sci 11:1633-1644. https://doi.org/10.5194/hess-11-1633-2007

Pons A, Allamy L, Schüttler A, Rauhut D, Thibon C, Darriet P (2017) What is the expected impact of climate change on wine aroma compounds and their precursors in grape? OENO One 51:141146. https://doi.org/10.20870/oeno-one.2017.51.2.1868

R Core Team (2013) R: A language and environment for statistical computing. R Foundation for Statistical Computing, Vienna, Austria. https://www.R-project.org/

Ramos Martín MC, Jones GV, Yuste J (2018) Phenology of Tempranillo and Cabernet-Sauvignon varieties cultivated in the Ribera del Duero DO: observed variability and predictions under climate change scenarios. OENO One 52:31-44. https://doi.org/10.20870/ oeno-one.2018.52.1.2119

Rebetez M (2001) Changes in daily and nightly day-to-day temperature variability during the twentieth century for two stations in Switzerland. Theor Appl Climatol 69:13-21. https://doi.org/10. 1007/s007040170032

Rebetez M, Reinhard M (2008) Monthly air temperature trends in Switzerland 1901-2000 and 1975-2004. Theor Appl Climatol 91:27-34. https://doi.org/10.1007/s00704-007-0296-2

Resolution OIV VITI 423-2012 (2012) OIV guidelines for vitiviniculture zoning methodologies on a soil and climate level. Adopted by the 10th General Anssembly of the OIV. Izmir, Turkey

Riou C et al (1994) Le déterminisme climatique de la maturation du raisin application au zonage de la teneur en sucre dans la Communauté européenne. Office des publications officielles des Communautés européennes, Luxembourg

Santillán D, Iglesias A, La Jeunesse I, Garrote L, Sotes V (2019) Vineyards in transition: a global assessment of the adaptation needs of grape producing regions under climate change. Sci Total Environ 657:839-852. https://doi.org/10.1016/j.scitotenv.2018.12.079

Santos JA, Fraga H, Malheiro AC, Moutinho-Pereira J, Dinis LT, Correia C, Moriondo M, Leolini L, Dibari C, Costafreda-Aumedes S, Kartschall T, Menz C, Molitor D, Junk J, Beyer M, Schultz HR (2020) A review of the potential climate change impacts and adaptation options for European viticulture. Appl Sci 10:1-28. https://doi.org/10.3390/app10093092

Schultz HR (2000) Climate change and viticulture: a European perspective on climatology, carbon dioxide and UV-B effects. Aust J Grape Wine Res 6:2-12. https://doi.org/10.1111/j.1755-0238. 2000.tb00156.x

Seguin B, Garcia de Cortazar I (2005) Climate warming: consequences for viticulture and the notion of 'terroirs' in Europe. In International Society for Horticultural Science (ISHS), Leuven, Belgium. Acta Hortic 689:61-70. https://doi.org/10.17660/ActaH ortic.2005.689.3

Sgubin G, Swingedouw D, Dayon G, García de Cortázar-Atauri I, Ollat N, Pagé C, van Leeuwen C (2018) The risk of tardive frost damage in French vineyards in a changing climate. Agric For Meteorol 250-251:226-242. https://doi.org/10.1016/j.agrformet.2017.12. 253
Shaw TB (2012) A climatic analysis of wine regions growing pinot noir. J Wine Res 23:203-228. https://doi.org/10.1080/09571264. 2012.697356

Spayd SE, Tarara JM, Mee DL, Ferguson JC (2002) Separation of sunlight and temperature effects on the composition of vitis vinifera cv. Merlot berries. Am J Enol Vitic 53:171-182

Spring J-L, Zufferey V (2009) Influence de l'irrigation sur le comportement de la vigne et sur la qualité de vins rouges dans les conditions du Valais central. Rev Suisse Vitic Arboricult Hortic 41:103-112

Stock M, Gerstengarbe FW, Kartschall T, Werner PC (2005) Reliability of climate change impact assessments for viticulture. In International Society for Horticultural Science (ISHS), Leuven, Belgium. Acta Hortic 689:29-40. https://doi.org/10.17660/ActaH ortic.2005.689.1

Tate AB (2001) Global warming's impact on wine. J Wine Res 12:95109. https://doi.org/10.1080/09571260120095012

Tomasi D, Jones GV, Giust M, Lovat L, Gaiotti F (2011) Grapevine phenology and climate change: relationships and trends in the Veneto region of Italy for 1964-2009. Am J Enol Vitic 62:329_ 339. https://doi.org/10.5344/ajev.2011.10108

Tonietto J, Carbonneau A (2004) A multicriteria climatic classification system for grape-growing regions worldwide. Agric For Meteorol 124:81-97. https://doi.org/10.1016/j.agrformet.2003.06.001

Unwin T (2005) Wine and the vine: an historical geography of viticulture and the wine trade. Routledge, London

Urhausen S, Brienen S, Kapala A, Simmer C (2011) Climatic conditions and their impact on viticulture in the Upper Moselle region. Clim Change 109:349-373. https://doi.org/10.1007/ s10584-011-0059-z

van Leeuwen C, Darriet P (2016) The impact of climate change on viticulture and wine quality. J Wine Econ 11:150-167. https:// doi.org/10.1017/jwe.2015.21

van Leeuwen C, Friant P, Choné X, Tregoat O, Koundouras S, Dubourdieu D (2004) Influence of climate, soil, and cultivar on Terroir. Am J Enol Vitic 55:207-217

van Leeuwen C et al (2013) Why climate change will not dramatically decrease viticultural suitability in main wine-producing areas by 2050. Proc Natl Acad Sci 110:E3051-E3052. https://doi.org/10. 1073/pnas. 1307927110

van Leeuwen $\mathrm{C}$, Trégoat $\mathrm{O}$, Choné $\mathrm{X}$, Bois $\mathrm{B}$, Pernet $\mathrm{D}$, Gaudillère J-P (2009) Vine water status is a key factor in grape ripening and vintage quality for red Bordeaux wine. How can it be assessed for vineyard management purposes? OENO One 43:121-134. https:// doi.org/10.20870/oeno-one.2009.43.3.798

Wolkovich EM, García de Cortázar-Atauri I, Morales-Castilla I, Nicholas KA, Lacombe T (2018) From Pinot to Xinomavro in the world's future wine-growing regions. Nat Clim Change 8:29-37. https://doi.org/10.1038/s41558-017-0016-6

Publisher's Note Springer Nature remains neutral with regard to jurisdictional claims in published maps and institutional affiliations. 